\title{
The role of red betel extracts (piper crocatum ruiz \& pav.) against testicular assessment on mice model of rheumatoid arthritis
}

\begin{abstract}
Rheumatoid arthritis (RA) is a chronic inflammatory disease that often followed by hypogonadism and low level of testosterone. RA is also followed by the increase in free radical causing lipid peroxidation on the spermatozoa cell membrane. The reproductive disorder caused by RA could end up with infertility. Red betel (Piper crocatum Ruiz $\&$ Pav.) is a plant usually used as a traditional medicine since it contains flavonoid functioning as an antioxidant and anti-inflammatory. This research aims to analyze the effect of red betel extract (RBE) on the recovery of reproduction physiology of male mice model of RA induced with Complete Freud Adjuvant. The 24 Swiss strain male mice were divided into six groups: non-treatment, RA only, RA+Aspirin of $0,013 \mathrm{mg}$ / $\mathrm{kg} \mathrm{BW}$, and RBE doses of $100 \mathrm{mg} / \mathrm{ml}, 200 \mathrm{mg} / \mathrm{ml}$, and $400 \mathrm{mg} / \mathrm{ml}$, sequentially. RBE and aspirin were given to the mice orally for 30 days. Aspirin was used as a medicine control. On the 31 st day, the mice were dissected, the serum was taken from heart for analysis of testosterone and the testis was taken for evaluating the testis weight, testis index and seminiferous tubules diameter. The research result showed that RBE had no effect on testis weight but it influenced testis index, seminiferous tubules diameter and testosterone $(\mathrm{p}<0.05)$. RBE had potential for repairing the characteristic of male reproduction on mice model of RA.
\end{abstract}

Keywords: red betel extract, testosterone, testis weight, testis index, seminiferous tubules diameter
Research Article

Volume II Issue I - 2018

\begin{abstract}
Abdul Gofur, Sri Rahayu Lestari
Department of Biology, Universitas Negeri Malang, Indonesia

Correspondence: Sri Rahayu Lestari, Department of Biology, Faculty of Mathematic and Natural Science, Universitas Negeri Malang (State University of Malang), Jl. Semarang 5, Malang, Indonesia, Email srirahayulestari@um.ac.id
\end{abstract}

Received: February 13, 2018 | Published: February 28, 2018

\section{Introduction}

Rheumatoid Arthritis (RA) is an autoimmune disease causing chronic inflammatory and degeneration of connective tissue of synovial membrane ${ }^{1,2}$ RA disease is usually indicated by swelling on wrist, leg, and knee. Other symptoms of RA patient are fatigue and mild fever. ${ }^{3}$ The prevalence of RA disease is widespread in the world attacking around $0.5-1 \%$ of the population. This disease could attack all ages but commonly at the age of $40-60$ years.

RA is a chronic inflammatory disease that closely related to reproduction health. Men who suffer from RA are usually followed by hypogonadism, ${ }^{4}$ testicular dysfunction, ${ }^{5}$ and the low level of testosterone. ${ }^{6}$ In addition, testicular macrophage is also active in secreting factors of pro-inflammatory disturbing the path of testosterone production signaling. ${ }^{7}$ RA condition is also followed by the increase in lipid peroxidation on Reactive Oxygen Species (ROS) stimulating lipid peroxidation on the cell membrane of spermatozoa. Spermatozoa are vulnerable to damage caused by oxidative stress since the plasma membrane of spermatozoa contains a large amount of polyunsaturated fatty acids (PUFA), and its cytoplasm contains antioxidant enzyme in a low concentration. ${ }^{8}$ Thus, it could cause the decrease in quality and function of spermatozoa that leads to infertility. ${ }^{9}$ An alternative treatment using natural materials to recover the reproduction health caused by RA is preferred by the society since it is safer, cheaper and less side effect. ${ }^{10}$

One of the plants used by Indonesian people as a traditional medicine is red betel leaf (Piper crocatum Ruiz \& Pav). Red betel plant functions as anti-mutagen, detoxification agent, ${ }^{11}$ anti-inflammatory, ${ }^{12}$ and antioxidant. ${ }^{13}$ The result of previous research of cytotoxicity test showed that red betel extract could be used as a safe natural material. ${ }^{13}$ However, the role of red betel extract as an anti-inflammatory as the result of CFA induction in reproduction system has rarely been known. This research aims to know the effect of red betel extract on the recovery of the reproductive system of RA mice model. The research result is expected to be able to provide a well understanding of male reproduction system recovery on RA using natural material.

\section{Materials and methods}

\section{Plant material and extraction}

Red betel leaf was obtained from Balai Materia Medica, Batu, East Java. Simplicia of red betel leaf was dissolved using ethanol of $70 \%$ through percolation method. The last step was evaporating using rotary evaporator until a semi-solid result was obtained. The making of the stock solution was conducted by taking $1 \mathrm{~g}$ of semisolid solution added with aquabidest up to $10 \mathrm{ml}$; then centrifuged at $10.000 \mathrm{rpm}$ for 5 minutes, so the stock solution was obtained with concentration of $100 \mathrm{mg} / \mathrm{ml}$.

\section{Experimental animals}

Seven weeks-24 Swiss strain mice weighing \pm 25 gram were divided into five groups randomly: non-treatment (NT), RA only, RA with aspirin of $0.013 \mathrm{mg} / \mathrm{kg} \mathrm{BW}$, and ESM with concentration of 100 $\mathrm{mg} / \mathrm{ml}, 200 \mathrm{mg} / \mathrm{ml}$, and $400 \mathrm{mg} / \mathrm{ml}$, sequentially. The treatment of 
aspirin and ESM was given in gastric tube once in a day for three weeks with the volume of $0.5 \mathrm{ml} / 20 \mathrm{~g}$ mice body weight. The making of RA animal model was done by injecting Complete Freund's Adjuvant (CFA) intraperitonally with the dose of $0.05 \mathrm{mg} / \mathrm{kg}$ BW only on the first day except in the normal group; it was then injected with $0.05 \mathrm{mg} / \mathrm{kg} \mathrm{BW}$ of Incomplete Freund's Adjuvant (IFA) on the subsequent week. Each mouse was fed with $25 \mathrm{~g}$ meal and the drink was given in ad libitum. The experimental protocol was approved by ethical clearance from the Research Ethics Committee, Medicinal Faculty, Brawijaya University (No. 538-KEP-UB-2015).

\section{Determination of testis weight and seminiferous tubules diameter}

Testis taken was weighed to get the testis index referring to the formulation of Yuan et al. ${ }^{14}$ and stored in formalin of $10 \%$. Next, a transverse section was made with Hematoxylin-Eosin (HE) staining. Seminiferous tubules diameter was examined using a microscope with 800x magnification.

\section{Testosterone analysis}

The blood was taken from the heart and kept for 30 minutes.
It was then centrifuged at velocity of $3000 \mathrm{rpm}$ for 15 minutes to obtain serum. The blood serum obtained was stored in the freezer at a temperature of $-20^{\circ} \mathrm{C}$ until it was ready to be used. The testosterone level was measured using ELISA technique at the wavelength of 450 $\mathrm{nm}$ based on the protocol stated in the product (Elabscience).

\section{Statistical analysis}

Data was analyzed using One Way ANOVA at a confidence level of $95 \%(\alpha=0,05)$. The statistical analysis was done using software SPSS 20.0 for windows. The data was presented in the form of average of \pm standard deviation (SD).

\section{Result}

The research result showed that there was no significant difference in testis weight between control and experiment groups (Figure 1A). The testis index, seminiferous tubules diameter, and testosterone level decreased significantly in the RA group $(\mathrm{p}<0.05)$ compare to the nontreatment group (Figure 1B-1D). The treatment of red betel extract could increase the testis index, seminiferous tubules diameter and testosterone level in the condition of RA. Aspirin used as the medicine control had better impact than the red betel extract.
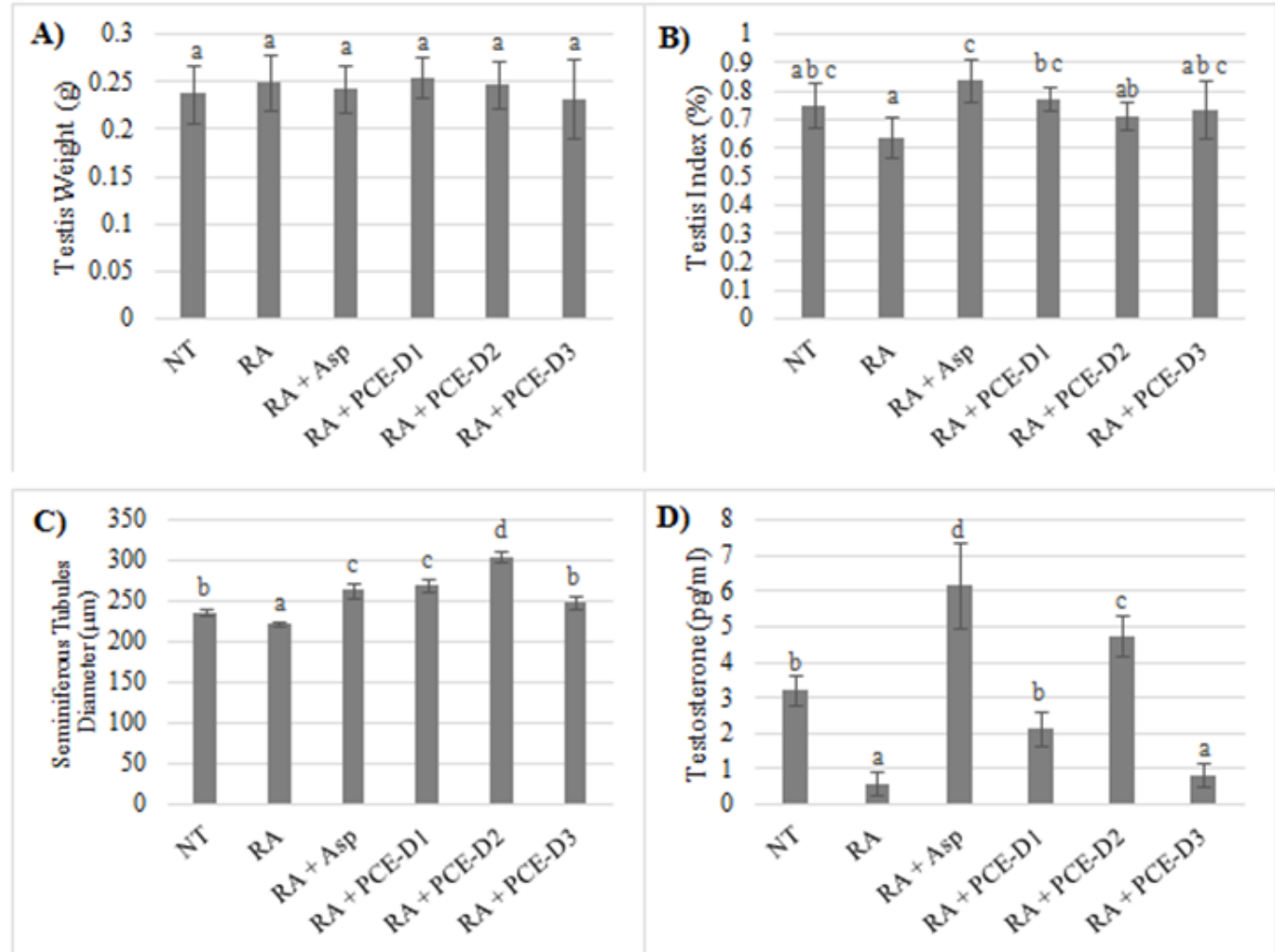

Figure I Male reproductive capability assessments.

a. Evaluation of reproductive capacity of male mice after CFA induction based on.

b. Testis weight, B. Testis index.

c. Seminiferous tubules diameter.

d. Testosterone level of each group of treatment.

NT, Non-treatment; RA, CFA only; Asp,Aspirin 0,013 mg/kg BW; DI-D3, treatment of red betel extract at a dose of I00, 200, $400 \mathrm{mg} / \mathrm{kg}$ BB respectively. The value is presented in the form of average of \pm standard deviation. Different notation shows significant difference $(p<0.05)$ in every group based on the Duncan post-hoc test. 


\section{Discussion}

Reproductive disorder is a serious complication that endangers the RA patient. ${ }^{15}$ The abundant free radical exposure causes the decrease in the number of spermatozoa, the change of pathology in the form of seminiferous tubules atrophy, the decrease in testis weight, degeneration and necrosis of spermatogenic cell, and the decrease in viability and motility of spermatozoa cell that will cause infertility. ${ }^{16}$ The research result showed that CFA induction could cause change in male mice reproduction. The treatment of red betel extract was able to recover the reproductive disorder in the condition of RA.

Red betel extract contained flavonoid functioning as a scavenger of superoxide anion and hydroxide radical. Flavonoid donates a hydrogen atom to the peroxide radical forming flavonoid radical that easily reacts with free radical, so the radical chain reaction stops. ${ }^{17}$ Flavonoid as an antioxidant had increased the number of the spermatogenic cell of the group, so the thickness of seminiferous tubules epithelial increased and influenced the testis weight.

Based on the working mechanism, flavonoid could act as an antioxidant that could repair the physiology of mice induced by CFA. The thickness of seminiferous tubules epithelial could cause an increase in testis weight. According to Lea et al. ${ }^{17}$ the number of seminiferous tubules spermatogenic cells in the testis can determine the growth of the testis weight.

Testosterone hormone is essential for the growth and fission of germinal cells so that the spermatogenesis process will work well and the numbers of sperm will increase. ${ }^{18}$ In this research, the testosterone hormone increased significantly after it was given red betel extract $(\mathrm{p}>0.05)$.

Physiologically, in the HHT portal system, the hypothalamus secretes FSH and LH; however, since CFA induction can cause the free radical to bind with the estrogen receptor, the FSH and LH secretions decrease. If LH secretion is inhibited, the growth and maturation of Leydig cell and the possibility of the number of Leydig cells are reduced thus the testosterone hormone secretion will reduce as well. It is because it is in the Leydig cell that steroidogenesis process resulting testosterone is occurred; if its number and function reduced, the production will reduce as well. The existence of antioxidant in the form of flavonoid can bind the free radical, so the FSH and LH secretions increase along with the increase in testosterone hormone.

\section{Conclusion}

RBE can repair the reproductive capacity of RA male mice model by increasing the testis index, seminiferous tubules diameter and testosterone serum. RBE can be used as natural material which is potential to heal the reproductive disorder for RA in the future. Further research is recommended to know the detailed mechanism of $\mathrm{RBE}$ in repairing the characteristic of male reproductive.

\section{Acknowledgements}

The authors thank PTT team on Universitas Negeri Malang for critical this article. We would say thank you to MF Atho'illah which helps this research.

\section{Conflict of interest}

None.

\section{References}

1. Cooles F, Isaacs D. Pathophysiology of Rheumatoid Arthritis. Curr Opin Rheumatol. 2011;23(5):233-240.

2. McInnes IB, Schett. Mechanisms of Disease the Pathogenesis of Rheumatoid Arthritis. N Engl J Med. 2011;365(23):2205-2219.

3. Samanta R, Shoukrey K, Griffiths R. Rheumatoid arthritis and anaesthesia. Anaesthesia. 2011;66(1):1146-1159.

4. Jiménez-Balderas FJ, Tápia-Serrano R, Fonseca ME, et al. High frequency of association of rheumatic/autoimmune diseases and untreated male hypogonadism with severe testicular dysfunction. Arthritis Res. 2001;3(6):362-367.

5. Cutolo M, Seriolo B, Villaggio B, et al. Androgens and estrogens modulate the immune and inflammatory responses in rheumatoid arthritis. Ann N Y Acad Sci. 2002;966:131-142.

6. Buvat J, Maggi M, Guay A, et al. Testosterone deficiency in men: systematic review and standard operating procedures for diagnosis and treatment. $J$ Sex Med. 2013;10(1):245-284.

7. Bruot BC, Clemens JW. Regulation of testosterone production in the adjuvant induced arthritic rat. J Androl. 1992;13(1):87-92.

8. Amaral S, Oliveira PJ, Ramalho-Santos J.Diabetes and the Impairment of Reproductive Function: Possible Role of Mitochon- dria and Reactive Oxygen Species. Curr Diabetes Rev. 2008; 4(1):46-54.

9. Fridovich I. Superoxide Dismutase in Advances in Enzymology and Related Areas of Molecular Biology. Adv Enzymol Relat Areas Mol Biol. 1986;58:61-97.

10. Rathee JS, Patro BS, Mula S, et al. Antioxidant activity of Piper betle leaf extract and its constituents. J Agric Food Chem 2006;54:90469054.

11. Aulanni'am, Roosdiana A, Rahmah NL. The Potency of Sargassum duplicatum Bory Extract on Inflammatory Bowel Disease Therapy in Rattus norvegicus. Journal of Life Sciences. 2012;6(2):144-154.

12. Milton Prabu S, Muthumani M, Shagirtha K. Protective effect of Piper betle leaf extract against cadmium-induced oxidative stress and hepatic dysfunction in rats. Saudi J Biol Sci. 2012;19(2):229-239.

13. Maslikah SIM, Lestari SR, Wulandari N. Active Compounds of Red betel (Piper crocatum) Extract for Safe Antioxidants as Cytotoxicity Test Revealed. International Journal of Chem Tech Research . 2016;4(9): 513-530.

14. Yuan XX, Zhang B, Li LL, et al. Effects of soybean isoflavones on reproductive parameters in Chinese minipig boars. J Anim Sci Biotechnol. 2012;3(1):31.

15. Bove R. Autoimmune diseases and reproductive aging. Clin Immunol. 2013;149(2):251-264.

16. Tang M, Xie Y, Yi Y, et al. Effect of Formaldehyde on Germ Cells of Male Mice. Wei Sheng Yan Jiu. 2003;32(6):544-548.

17. Leal MC, Becker-Silva SC, Chiarini-Garcia H, et al. Sertoli Cell Efficiency and Daily Sperm Production in Goats (Capra hircus). Journal of Animal Reproduction. 2004;1(1):122-128.

18. Valko M, Rhodes CJ, Moncol J, et al. Free Radical, Metal and Antioxidant in Oxidative Stress Inducced Cancer. Chem Biol Interact. 2006;160(1):1-40. 